\title{
Nursing appeals on social media in times of coronavirus
}

\author{
Os apelos da enfermagem nos meios de comunicação em tempos de coronavirus \\ Los llamamientos de enfermería en las redes sociales en tiempos de Coronavirus
}

Elaine Cristina Novatzki Forte' ORCID: 0000-0002-6042-5006

Denise Elvira Pires de Pires ORCID: 0000-0002-1754-0922

'Universidade Federal de Santa Catarina. Florianópolis, Santa Catarina, Brazil.

How to cite this article: Forte ECN, Pires DEP. Nursing appeals on social media in times of coronavirus. Rev Bras Enferm. 2020;73(Suppl 2):e20200225. doi: http://dx.doi.org/10.1590/0034-7167-2020-0225

Corresponding author: Elaine Cristina Novatzki Forte E-mail: elainecnforte@gmail.com

EDITOR IN CHIEF: Dulce Aparecida Barbosa ASSOCIATE EDITOR: Antonio José De Almeida Filho

Submission: 04-01-2020

Approval: 04-21-2020

\section{ABSTRACT}

Objective: to know and analyze the nursing appeals on social media during the COVID-19 pandemic. Method: it is a documentary, qualitative, descriptive, and exploratory research with data collected in publications in two social media. Two hundred ninety-five publications of nursing professionals published on Twitter and Instagram between March 11 and 20, 2020 were submitted to content analysis using ATLAS.ti resources. Results: four thematic categories emerged: \#stayathome, \#whereismyPPE, \#nowweareheroes, \#nothingnewinthefrontline, according to frequency of communications. The appeals show a relationship with the social relevance of nursing professional work and with the conditions required for its exercise. Final considerations: old and new challenges of the profession were placed on the agenda in social media, especially related to the workforce and instruments of labor. These speeches can serve as a foundation for policies to improve working conditions and promote appreciation of the profession.

Descriptors: Nursing; Working Conditions; Communications Media; Coronavirus Infections; SARS Virus.

\section{RESUMO}

Objetivo: conhecer e analisar os apelos da Enfermagem nas mídias sociais durante a pandemia de COVID-19. Método: pesquisa documental, qualitativa, descritiva e exploratória, com dados coletados em publicações em duas mídias sociais, submetidos à análise de conteúdo utilizando recursos do software ATLAS.ti. Foram analisadas 295 publicações de profissionais de enfermagem veiculadas no Twitter e no Instagram entre os dias 11 e 20 de março de 2020. Resultados: organizados em quatro categorias temáticas: \#fiqueemcasa, \#cadêmeuEPI, \#agorasomosheróis, \#nadadenovonofront, segundo frequência nas comunicações. Os apelos mostram relação com a utilidade social do trabalho profissional e com condições requeridas para seu exercício. Considerações finais: antigos e novos desafios da profissão foram colocados em pauta nas mídias sociais, especialmente relacionados aos instrumentos de trabalho e à própria força de trabalho. Esses discursos podem servir de alicerce para políticas de melhoria das condições trabalho e fomentar a valorização da profissão.

Descritores: Enfermagem; Condições de Trabalho; Meios de Comunicação; Infecções por Coronavirus; Virus da SARS.

\section{RESUMEN}

Objetivo: conocer y analizar las llamadas de enfermería en las redes sociales durante la pandemia de COVID-19. Método: investigación documental, cualitativa, descriptiva y exploratoria, con datos recopilados en publicaciones en dos redes sociales, sometidos a análisis de contenido utilizando recursos del software ATLAS.ti. Se analizaron 295 publicaciones de profesionales de enfermería publicadas en Twitter e Instagram entre el 11 y el 20 de marzo de 2020. Resultados: fue organizado en cuatro categorías temáticas: \#quédeseencasa, \#dóndeestámiEPP, \#ahorasomoshéroes, \#nadanuevoenlalíneadefrente, según la frecuencia en las comunicaciones. Las apelaciones muestran una relación con la utilidad social del trabajo profesional y las condiciones requeridas para su ejercicio. Consideraciones finales: los viejos y nuevos desafíos de la profesión se colocaron en la agenda de las redes sociales, especialmente en relación con las herramientas de trabajo y la propia fuerza laboral. Estos discursos pueden servir de base para políticas que mejoren las condiciones de trabajo y promuevan la apreciación de la profesión. Descriptores: Enfermería; Condiciones de Trabajo; Medios de Comunicación; Infecciones por Coronavirus; Virus del SRAS. 


\section{INTRODUCTION}

On December 30, 2019, the world began to worry about a new health problem from three samples collected from a patient with pneumonia of unknown etiology at Wuhan Jinyintan Hospital. Examinations indicated the presence of a virus with characteristics of the coronavirus family, due to the typical crown-shaped particles when observed in the transmission electron microscope ${ }^{(1)}$.

On February 20,2020, less than two months from the first case in China, more than 75,000 cases of COVID-19 were reported in that country. The reported cases are based on the National Reporting System (NRS), which issues daily reports of new confirmed cases, deaths, suspected cases, and contacts ${ }^{(1)}$. A daily report is provided, by province, reporting the cases from the previous day ${ }^{(1)}$.

On March 11, 2020, the World Health Organization (WHO) declared COVID-19 as a pandemic, with Italy as the new contamination epicenter. In Brazil, the first case was announced on February 26, 2020. Until April 1, 2020, 885,687 cases were confirmed worldwide, with 44,216 deaths, and in Brazil, 5,861 cases of the disease and 203 deaths were already confirmed ${ }^{(2)}$.

The WHO estimates the lethality rate for this virus around $3.4 \%$, being the highest in China and the group of asymptomatic individuals is very low, around $1 \%{ }^{(3-4)}$. The lethality by COVID-19 between 0.5 to $4 \%$ is similar to that of the Spanish flu $^{(4)}$ and is much higher in relation to influenza $\mathrm{A} \mathrm{H} 1 \mathrm{~N} 1^{(5-6)}$ or the seasonal flu ${ }^{(7-8)}$.

Among the main measures adopted by China to drastically reduce transmission rates stood out are: border control; identification of the etiological agent; social contact restrictions; protection of health professionals with appropriate personal protective equipment (PPE); identification of symptomatic patients, testing, quick results and isolation; identification of communicators and quarantine ${ }^{(8)}$. A Brazilian epidemiologist ${ }^{(8)}$ states that "the evolution of the epidemic is uncertain [...] and Brazil has the capacity to overcome this challenge, as SUS is one of the largest public health systems in the world, but intense social mobilization is needed".

To face the pandemic, health professionals, researchers in the area and health authorities are essential, as well as the need for society to be involved. The records of the process, evolution and measures to cope with the pandemic show what the literature has described about health work: the result depends on the collaboration between those who perform and those who receive care ${ }^{(9)}$; universal access to health is a challenge for nations and requires investment ${ }^{(10)}$; its effectiveness requires intersectoriality, work tools in adequate quantity and quality, with a strong investment in innovative technologies, at the same time that it is highly dependent on the workforce ${ }^{(11)}$.

Faced with the COVID-19 pandemic, health professionals, among them those in nursing, are the front line for treatment, prevention, and recovery of cases. Nursing professionals are at the entrance door and in all the assistance in health services. In hospital-type institutions, health professionals follow patients 365 days a year, uninterruptedly. In Brazil, there are more than two million professionals with secondary and higher education registered with the Federal Nursing Council (Conselho Federal de Enfermagem) $)^{(12)}$. A large part of these professionals are in the labor market, in health care, educational institutions, in management positions and involved in research, which are fundamental activities for the health of the population and for the fight against the coronavirus. Nursing is at the forefront of the pandemic, working to promote the health of the population and taking care of people with health problems already installed.

This year marks the bicentenary of the birth of Florence Nightingale and was declared by the World Health Organization (WHO) as the "International Year of the Nurse and the Midwife" "International Year of Nursing", as we call it in Brazil. This year also ends the triennium of the Nursing Now campaign, an initiative of the International Nursing Council (ICN), WHO and the British Parliament that has spread around the world ${ }^{(13)}$. The campaign aims to enhance and give visibility to the work of nursing in view of its importance for the health of populations. This appeal has never been timelier and more necessary.

In the current world, strongly influenced by global communication in real time, social media has stood out as a vehicle for expression of people, organizations and also of nursing. These resources have been used in a very creative and promising way to show the nursing profession to society, what it does and the importance of this work in all contexts of promoting and protecting people's health. In times of pandemic, which has left the whole world on alert and concerned, professionals have made appeals on social media, since they are constantly exposed to situations of risk of contamination by the virus, but which, due to the nature of the profession, cannot have the choice to get away, like the others.

This setting instigates arises questions as: what appeals have nursing professionals expressed on social media?

\section{OBJECTIVE}

To know and analyze the nursing appeals on social media during the coronavirus pandemic.

\section{METHOD}

\section{Ethical aspects}

This study, having as source data collection, publications on free-access social media, does not need approval in ethics committees in research with human beings. However, in order to maintain the recommendations in Resolution 466/2012 of the Brazilian National Health Council (Conselho Nacional de Saúde), which determines the provisions for research involving human beings, the anonymity of all authors of the publications was guaranteed.

\section{Theoretical-methodological framework and type of study}

This qualitative, descriptive, and exploratory study was based on documents, guided by Karl Marx's Labour Process theory, for understanding the work of nursing in the historical and social context in which it is inserted ${ }^{(14)}$. This study was also based on the Sociology of Professions and the Theory of Communicative Action by Jürgen Habermas, which allows the understanding of language as action, in the sense that communication provides actions through interaction and rationality ${ }^{(15)}$. 


\section{Study setting and data source}

The study setting consists of two social medias, Twitter and Instagram, through their publications in Brazil. Available data online totaled 295 publications by nursing professionals, with 101 on Twitter and 194 on Instagram. Search for publications took place from March 11, 2020, when the WHO declared the coronavirus pandemic until March 20, 2020, when the Brazilian government declared a state of public calamity.

\section{Data collection and organization}

The crossing of the hashtags \#nursing and \#coronavirus was used to collect data on Twitter and Instagram.

Search for publications on Twitter occurred using ATLAS.ti (Qualitative Data Analysis) tool, version 8.4.24.0. This tool makes it possible to import and export different databases, in which simultaneous semantic analysis takes place, based on what is proposed in the search.

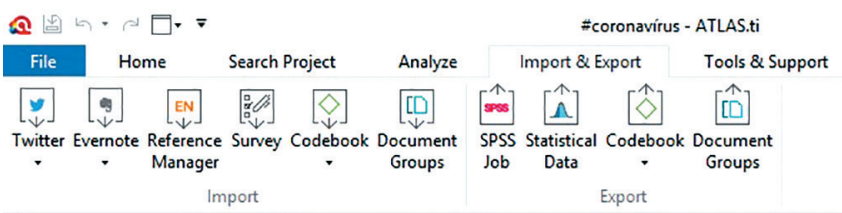

Figure 1 - Interface of ATLAS.ti import

Within the project called \#coronavirus in software, the search for tweets was determined, and from this initial search, a document was generated containing all publications identified in the search. The imported data was automatically coded based on the selection made using hashtags, obtaining 101 initial codes, which were analyzed.

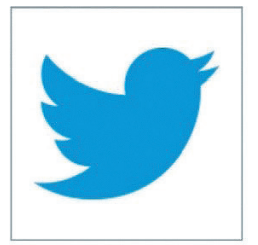

\section{ATLAS.ti Twitter Import}

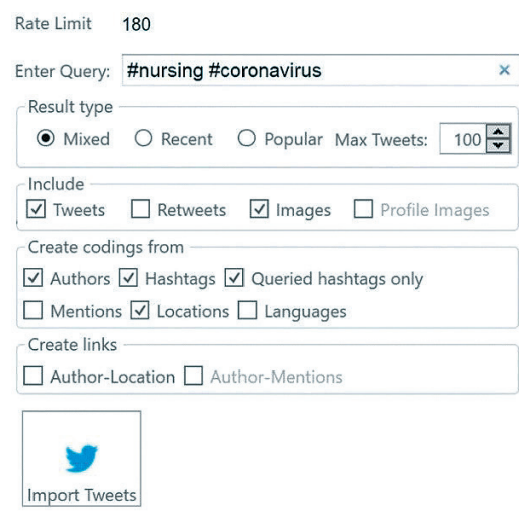

Figure 2 - Screen for importing data on Twitter

For data search on Instagram, the tool used was the magnifying glass of social media itself, placing the same hashtags. The total number of publications was exported to an Excel spreadsheet and that spreadsheet was imported into ATLAS.ti. In the Instagram, the software generated, through automatic coding, 194 codes.

\section{Data analysis}

The codes generated by ATLAS.ti were subsequently analyzed, through Thematic Content Analysis, to form groups/categories of coding expressed in the results of this study according to the largest number of publications, adding up to four categories, which were named with a hashtag, which represent the grouping of the analyzed content and the communication expressed in the analyzed content, being: \#stayathome, \#whereismyPPE, \#nowweareheroes, \#nothingnewinthefrontline.

Analysis was carried out according to the semantics of the words within the 295 publications of the two social media analyzed, according to the highest number of times that the hashtags \#nursing and \#coronavirus appeared together. Although this is a qualitative study, the number of citations was taken into account to demonstrate the importance of the nursing professionals'appeals in their publications.

\section{RESULTS}

The results are presented by thematic category considering the numerical order of citations.

\section{\#stayathome}

With a very expressive number (95 publications), nursing professionals made mass appeals asking people to stay at home during the quarantine period stipulated by state and municipal governments. The publications used different tools to sensitize the population, especially the elderly, to remain in their homes as a preventive measure and to promote the flattening of the virus spread curve.

The photos that most circulated in the media were taken by professionals in their work environments (hospitals, clinics, Emergency Care Units and Basic Health Units), wearing PPE and with signs in their hands with the phrase that ran the world: "We are here for you, stay home for us!"

At the moment thousands of health professionals are out of their homes facing the coronavirus. We ask you two things, pray for us and stay at home! \#stayathome \#covid \# covid19 \#corona \#nursing \#pandemic \#fighting \#coronavirus

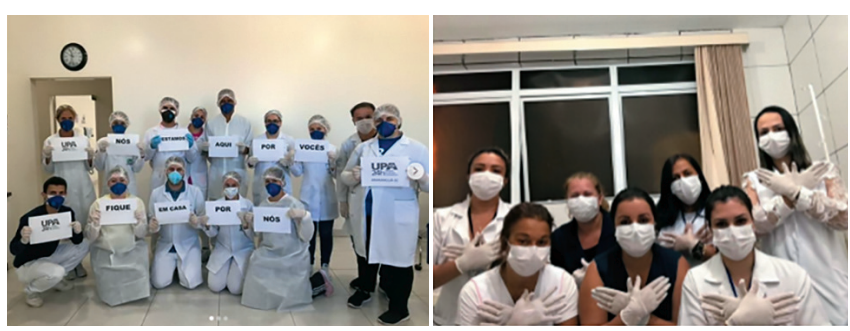

Caption: Picture on the left: we are here for you, stay at home for us. Figure 3 - Content taken from Instagram and Twitter, respectively - freely accessible

\section{\#whereismyPPE}

The appeal for more impact, which directly refers to professionals who work in assistance, is undoubtedly the requests for PPE (86). Many professionals have come to the public to demand 
that health institutions and authorities provide, as quickly as possible, the essential materials for the protection of all health professionals and patients.

If every soldier needs clothes and equipment for a war... where's mine!? WHERE'S MY PPE? How to fight a good fight, without PPE? WHERE'S MY PPE? \#coronavirus \#coronavirusinbrazil \#ccih \#nursing \#righttolife \#God \#alwaysfighting

I only enter the hospital, if I have PPE, a lack of humanity this with us at this moment. \# coronavirus \#coronavirusnobrasil \#ccih \#enfermagem

Among the appeals, there were many criticisms and denunciations, as shown below in the information that $\mathrm{N} 95$ respirators are recommended only for medical use, and the complete lack of equipment and alcohol.
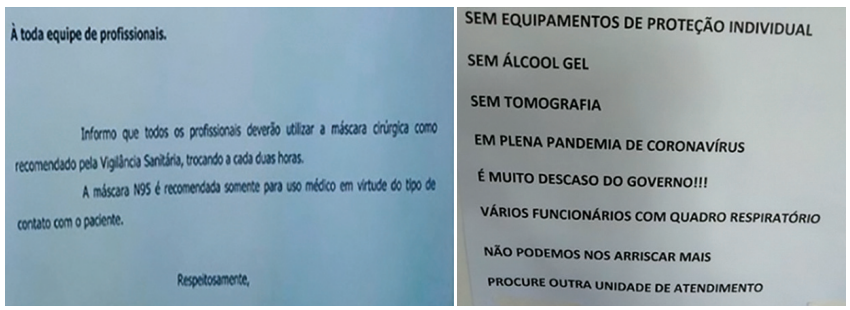

Caption: First notice: to all health professionals, I inform that all professionals must use surgical masks as recommended by the Sanitary Surveillance, exchanging them every two hours. N95 respirators are recommended only for medical use due to the type of contact with patients. Sincerely yours; Second notice: no PPE, no gel alcohol, no tomography in this coronavirus pandemic, the government is indifferent about it!!! There are many employees with respiratory symptoms, we cannot take risks anymore, look for another health unity.

Figure 4 - Parts of publications with clippings from professional communications

\section{\#nowweareheroes}

Everyone likes be honored and be called heroes, however, from other people's publications calling nursing professionals heroes, some appeals took shape after thanking them for their affection. These appeals, which totaled 70 publications, refer to the workday, absence of a decent salary floor and special retirement plan, to precarious working conditions and to the valorization of work.

Ask the government if, after all, they will create minimum wage for nursing! If they [government and legislative] are going to approve the $30 \mathrm{~h}$ of nursing! We are on the streets, stay at home! \#Coronavirus \#COVID-19 \#nurse \#Nursing \#stayathome

ANOTHER DAY (of tiredness, psychological pressure, discomfort behind the mask fogging up the glasses and of responsibility) WON! \#covid19 \#nurse \#nursing \#coronavirus

While many are at home protecting themselves, our work continues. In the fight against Coronavirus, respect is essential. Value those on the front lines of this battle! Acknowledge the work of nursing professionals. \#nursing \#covid19 \#coronavirus

We love the applauses, the homages, but I was wondering if after all this, when we go on strike and demand better working conditions, we will still be heroes. \#Coronavirus \#COVID-19 \#nurse \#Nursing \#stayathome \#valuenursing

Behind the mask: fear, fear, tiredness, pressure, worry, fear, distress, insecurity, fear. Did I say fear? The famous front line that cannot go back. Reverse? Not even to get an impulse. \# COVID19 \#Nurse \#Nurse \#coronavirus \#Nursing

\section{\#nothingnewinthefrontline}

Many of the professionals' appeals refer to educational aspects (44 publications), one of the dimensions of nursing work. The social media has become a good way for people education at this critical moment. Education is not a new way of prevention for nursing professionals, it is part of the daily work and helps to change people's lives.

The contents of publications that aim to educate the population are related to correct washing of hands, use of $70 \%$ alcohol for antisepsis and cough etiquette. Even in the face of a totally new situation, the professionals working show their capacity for awareness, guidance, and preventive measures, which are very peculiar in the profession.

HAND WASH - FOOTSTEPS! *Pass forward, we will respect the quarantine and we will end this virus *\#CoronavirusDuty \#MeintheQuarantine \#stayathome \#Day5 \#Covid_19\#coronavirus \#TotalQuarantine \#COVID19 \#HealthcareProfessionals \#AllAgainstCoronavirus

The nurse and researcher [name of the researcher] clearly and objectively explains some important points about \#coronavirus [video in publication]

COVID-19 - Home care, with Prof Dr [name of professor], Professor at Paulista School of Nursing-UNIFESP. Access: youtu. be/X7SBiCr2LWs

Photos and videos with images similar to the one in Figure 5 were seen in the searched media very often, reiterating care with hand washing.

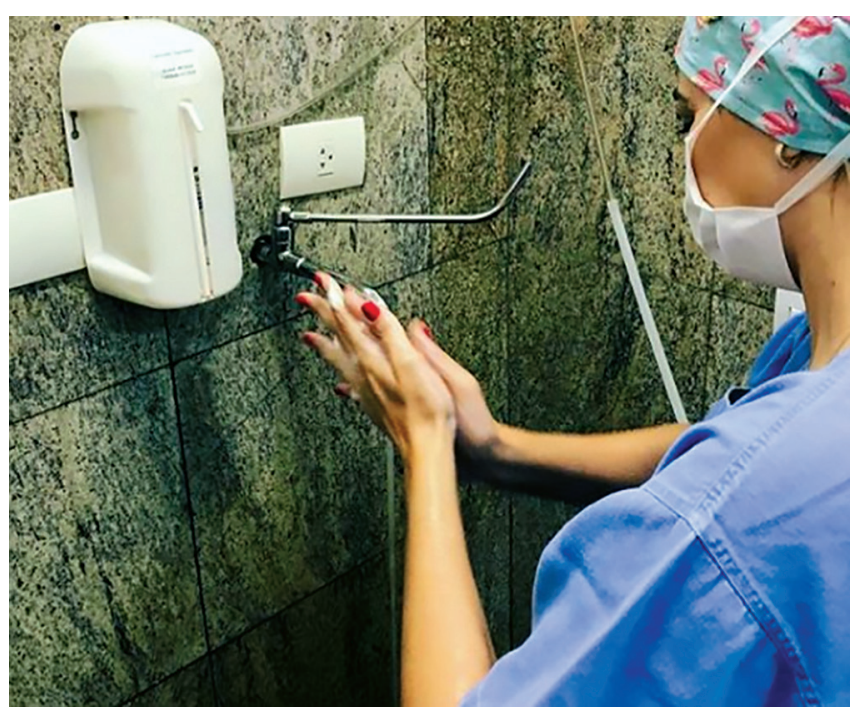

Figure 5 - Photography in which a nurse teaches how to wash hands properly 


\section{DISCUSSION}

In the daily life of health services and in critical situations, such as the coronavirus pandemic that is plaguing the world in 2020, nursing stands out in caring for people, in curative, preventive, rehabilitation and relief actions suffering and health promotion, developing work with professional characteristics ${ }^{(9)}$.

Nursing appeals on social media in times of coronavirus, the object of this study, show two major aspects of a professional-type job. First, the identity of those who practice nursing with a practice of strong social relevance, visible in the messages grouped in the hashtags \#stayathome and \#nothingnewinthefrontline, directly related to the people who are their object of work. Second, the defense of appropriate conditions for professional practice, visible in the hashtags \#whereismyPPE and \#nowweareheroes, related to the workforce and the conditions required to carry out work with this expertise and usefulness for human life.

One of the most effective measures to minimize the risk of contamination by the coronavirus and to extend the spread period is social isolation. This has been the most widely adopted measure in countries with confirmed disease cases, to avoid crowding and contagion to cause the numbers of cases to rise rapidly. The introduction of quarantine measures at the beginning of an outbreak can delay the introduction of the disease or the peak of an epidemic in an area where transmission is in progress ${ }^{(16)}$. In the context of the current outbreak of COVID-19, the global containment strategy setting includes the rapid identification of confirmed cases in the laboratory and their isolation and management of medical facilities $^{(17)}$ or at home ${ }^{(18)}$.

Delaying the course of the disease in a country is the most effective way of not overburdening health systems, which in some countries, such as Brazil, already suffer the consequences of health problems common to their populations. The implementation of such measures requires an unusual and unprecedented speed of decision-making by leaders, operational rigor by public health systems and the engagement of society, to gain weeks or months necessary for drug testing and vaccine development ${ }^{(1)}$. Therefore, nursing as a fundamental part of the Brazilian Unified Health System (Sistema Único de Saúde, abbreviated SUS), has been engaged every day, since the beginning of the epidemic, to raise awareness by asking for the hashtag \#stayathome. As language is action, this request, coming from a professional of unique importance for the society, may have a better effect.

Even in the face of so many challenges, even greater than they are used to facing in the daily life of the profession, nursing has devoted time and creativity on social media to educate society, whether in a simple and didactic explanation of how to wash your hands correctly, whether in videos designed to encourage home hygiene and respiratory etiquette. Therefore, there is nothing new on the front, this is one of the dimensions of the nursing work process continuously performed by nurses from all over the world.

Health education is a premise of nursing of extreme importance, and is based on people's culture, knowledge and previous experiences, and needs to be aligned with the ethical and legal aspects of the profession ${ }^{(19-20)}$. In the area of health, especially nursing, educating aims to change attitudes and behaviors, improving health outcomes by transforming reality. Educating, in nursing, is inherent to care, they are inseparable attitudes for comprehensive and quality nursing care ${ }^{(20)}$.

By teaching hygiene measures, through the dissemination of photos, videos and inserts, nursing fulfills its mission of caring for people, because through education it prevents diseases and promotes health.

As well as isolation, the use of PPE, instruments of labor to ensure the safety of workers and patients, is essential for the biosafety of nursing teams, as they are the people most at risk of contracting the disease because they are in contact with patients with COVID-19(21). This inevitably puts them at risk of getting the infection, so one of the goals in China was to protect healthcare professionals ${ }^{(1)}$. To assess these risks, WHO published on March 19, 2020, a data collection form to be used to identify violations of protection standards and define policies aimed at mitigating the exposure of professionals ${ }^{(21)}$.

A review study indicates that the absence of adequate PPE contributes to occupational exposure of nursing. Risk situations, which could be avoided, occur due to the absence of appropriate PPE, often a situation imposed by the employer ${ }^{(22)}$. PPE's must be understood as essential equipment in the nursing work routine, therefore, the regulatory norm of work n. 6 (from the Brazilian government) determines that the employer is responsible for the free distribution of PPE's ${ }^{(23)}$. The most evident appeal in the publications analyzed on PPE refers to face masks that protect professionals from droplets or aerosols that cause respiratory transmission diseases ${ }^{(24)}$. Even surgical face masks, which are not considered a PPE, as are not efficient as a barrier for respiratory tract infections, has not been made available as it should. For this reason, the question \#whereismyPPE? took a considerable part of the discussions in this period, so that nursing workers are not subjected to infection due to the lack of something inherent to their work process, the instruments that aim to protect them.

Many countries have witnessed very generous and simple expressions to honor and thank health professionals in this troubled period of the epidemic. They are applauding at the windows of people's homes, usually at night. It's exciting, indeed! In the face of so much recognition, nursing professionals are grateful on social media and take the opportunity to draw attention to what has long gone unnoticed: the working conditions of this profession.

Working conditions refer to the "work environment and all circumstances that affect work"(25), therefore, they are the factors that influence work, such as working hours, relationships, forms of organization, salary and rights. In this sense, for a long time, nursing has been struggling to achieve, by law, that its weekly workday does not exceed 30 hours and a decent wage floor, in addition, of course, to special retirement, given the nature of work. However, these claims, although always on the agenda of representative entities, seem to have no relevance for those who have the power to change this situation, the legislative power.

In Brazil, the struggle for a Bill of Law 2,295/2000, which establishes 30 hours per week as maximum working hours for nurses, technicians and nursing assistants, enter into force in 2011 and 2012 with the various political actions performed by representative entities and unions, but without success. However, if communication has the power to promote changes in practice, these appeals may come at a good time, so that, after this storm (coronavirus epidemic), society and legislature will look more vigorously at these demands of the profession. 
Therefore, in addition to the speeches of heroism stamped in a society historically sick due to the thirst for a stable economy, there are professionals who still suffer from the precariousness of work that has always made the difference between life and death, it just wasn't noticed before, because death may never have been this close.

\section{Study limitations}

The limitations refer to the choice of media, period of collection and incipience of studies in this same area, which could enrich the discussion.

\section{Contributions to nursing, health, and public policies}

This study can contribute to nursing to the extent that it gives visibility to its appeals in the face of an important crisis like this for public health, so that policy makers and society, as a whole, value the profession and understand the needs of these professionals, which have always been urgent, not just now during the coronavirus pandemic.

\section{FINAL CONSIDERATIONS}

By knowing and analyzing the appeals of nursing in times of the coronavirus pandemic, old challenges of the profession were placed on the agenda, especially related to the instruments and the workforce itself constantly exposed to risk situations due to precarious working conditions.

These speeches are relevant due to the current visibility of the profession, which unfortunately is connected by a cruel epidemic that has led to much suffering and death in several countries. Returning to the framework adopted in this study, that language, even though it is so peculiar to social media (through hashtags), serves as support for the changes that will come after the pandemic, in order to recognize and value professionals who have never away from caring for people.

Finally, keeping the memories of that historic moment, can serve as a foundation to remind society and policy makers, that in the worst moments of humanity, this profession has not ceased to be present. Therefore, let not be forgotten the palms at the window and thanks for the heroism, so that the profession can enjoy its deserved recognition.

\section{REFERENCES}

1. World Health Organization. Report of the WHO-China Joint Mission on Coronavirus Disease 2019 (COVID-19) [Internet]. World Health Organization; 2020 [cited 2020 Mar 29]. Available from: https://www.who.int/docs/default-source/coronaviruse/who-china-joint-missionon-covid-19-final-report.pdf

2. Johns Hopkins University. Coronavirus COVID-19 Global Cases by Johns Hopkins CSSE [Internet]. Johns Hopkins University; 2020 [cited 2020 Mar 29]. Available from: https://gisanddata.maps.arcgis.com/apps/opsdashboard/index.html\#/bda7594740fd40299423467b48e9ecf6

3. World Health Organization. WHO Director-General's opening remarks at the media briefing on COVID-19-3 March 2020 [Internet]. World Health Organization; 2020 [cited 2020 Mar 29]. Available from: https://www.who.int/dg/speeches/detail/ who-director-general-s-opening-remarks-at-the-media-briefing-on-covid-19---3-march-2020

4. Novel Coronavirus Pneumonia Emergency Response Epidemiology Team. The epidemiological characteristics of an outbreak of 2019 novel coronavirus diseases (COVID-19) in China. China CDC Wkly. 2020;41(2):145-51. doi: 10.3760/cma.j.issn.0254-6450.2020.02.003

5. World Health Organization. Pandemic Influenza preparedness and response: a WHO guidance document [Internet]. Geneva: World Health Organization; 2009 [cited 2020 Mar 29]. Available from: https://apps.who.int/iris/bitstream/handle/10665/44123/9789241547680_eng.pdf

6. Khandaker G, Dierig A, Rashid H, King C, Heron L, Booy R. Systematic review of clinical and epidemiological features of the pandemic influenza A (H1N1) 2009. Influenza Other Respir Viruses. 2011; 5(3):148-56. doi: 10.1111/j.1750-2659.2011.00199.x

7. Fauci AS, Lane HC, Redfield RR. Covid-19: Navigating the Uncharted. N Engl J Med. 2020;382:1268-9. doi: 10.1056/NEJMe2002387

8. Silva AAM. Sobre a possibilidade de interrupção da epidemia pelo coronavírus (COVID-19) com base nas melhores evidências científicas disponíveis. Rev Bras Epidemiol. 2020;23:e200021. doi: 10.1590/1980-549720200021

9. Pires DEP. A enfermagem enquanto disciplina, profissão e trabalho. Rev Bras Enferm. 2009;62(5):739-44. doi: 10.1590/S0034-71672009000500015

10. Atun R, Andrade LOM, Almeida G, Cotlear D, Dmytraczenko T, Frenz P, et al. Health-system reform and universal health coverage in Latin America. Lancet. 2015;385(9974):1230-47. doi: 10.1016/S0140-6736(14)61646-9

11. Gadelha CAGB, Costa OS. Health and innovation: economic dynamics and Welfare State in Brazil. Cad Saúde Pública. 2016;32(Suppl 2):e00150115. doi: 10.1590/0102-311X00150115

12. Conselho Federal de Enfermagem (BR). Enfermagem em números. [Internet]. 2020[cited 2020 Mar 28]. Available from: http://www.cofen. gov.br/enfermagem-em-numeros

13. Cassiani SHB, Lira Neto JCG. Perspectivas da Enfermagem e a Campanha Nursing Now. Rev Bras Enferm. 2018;71(5):2351-2. doi: 10.1590/0034-7167.2018710501

14. Marx K. O capital. 7. ed. resumida. Rio de Janeiro: Zahar editores; 1982.

15. Habermas J. Teoria do Agir Comunicativo 1: racionalidade da ação e racionalidade social. São Paulo: WMF Martins Fontes; 2012. 
16. World Health Organization. Considerations for quarantine of individuals in the context of containment for coronavirus disease (COVID-19): Interim guidance 28 February 2020. [Internet]. 2020 Feb [cited 2020 Mar 28]. Available from: https://www.who.int/publications-detail/ considerations-for-quarantine-of-individuals-in-the-contextof-containment-for-coronavirus-disease-(covid-19)

17. World Health Organization. Clinical management of severe acute respiratory infection (SARI) when COVID-19 disease is suspected. [Internet]. 2020[cited 2020 Mar 28]. Available from: https://www.who.int/publications-detail/ clinical-management-of-severe-acute-respiratory-infection-when-novel-coronavirus-(ncov)-infection-is-suspected

18. World Health Organization. Home care for patients with COVID-19 presenting with mild symptoms and management of their contacts: interim guidance, 17 March 2020[Internet]. Geneva: World Health Organization; 2020 [cited 2020 Mar 28]. Available from: https://www.who. int/publications-detail/home-care-for-patients-with-suspected-novel-coronavirus-(ncov)-infection-presenting-with-mild-symptoms-andmanagement-of-contacts

19. Wild CF, Nietsche EA, Salbego C, Teixeira E, Favero NB. Validação de cartilha educativa: uma tecnologia educacional na prevenção da dengue. Rev Bras Enferm. 2019;72(5):1318-25. doi: 10.1590/0034-7167-2018-0771

20. Nogueira-Jr C, Gama BMBM, Teixeira MS, Arreguy-Sena C. Educação em enfermagem: desafio diário para cuidar com excelência: análise da vivência de uma equipe. Rev Enferm Cent O Min [Internet]. 2011;1(4). doi: 10.19175/recom.v0i0.149

21. World Health Organization. Risk assessment and management of exposure of health care workers in the context of COVID-19, 19 March 2020. Geneva: World Health Organization; 2020 [Internet] [cited 2020 Mar 28]. Available from: https://apps.who.int/iris/bitstream/ handle/10665/331496/WHO-2019-nCov-HCW_risk_assessment-2020.2-eng.pdf

22. Moraes KKO, Almeida LF, Silva LPM, Santos MLGF, Silva ES, Jesus CS. Exposição da equipe de enfermagem aos riscos biológicos em unidade de terapia intensiva: revisão integrativa. Rev Inova Saúde [Internet] 2016 [cited 2020 Mar 28];5(2). Available from: http://periodicos.unesc. net/Inovasaude/article/view/3016/2955

23. Ministério do Trabalho e Emprego (BR). Secretaria de Inspeção do Trabalho. Portaria no 25 de 15 de outubro de 2001. Altera a Norma Regulamentadora que trata de Equipamento de Proteção Individual - NR 6, revoga a portaria que menciona, e dá outras providências. [Internet] 2001 [cited 2020 Mar 28]. Available from: http://www.lex.com.br/doc_22030_PORTARIA_N_25_DE_15_DE_OUTUBRO_DE_2001.aspx

24. Agência Nacional de Vigilância Sanitária. Cartilha de Proteção Respiratória contra Agentes Biológicos para Trabalhadores de Saúde. Brasília: ANVISA; 2000. [Internet] 2001 [cited 2020 Mar 28]. Available from: http://www2.ebserh.gov.br/documents/214604/816023/Car tilha+de+Prote\%C3\%A7\%C3\%A3o+Respirat\%C3\%B3ria+contra+Agentes+Biol\%C3\%B3gicos+para+Trabalhadores+de+Sa\%C3\%BAde. pdf/58075f57-e0e2-4ec5-aa96-743d142642f1

25. USLegal Dicionário. Working Conditions [Internet]. 2020 [cited 2020 Mar 28]. Available from: https://definitions.uslegal.com/w/ working-condition/ 